\title{
Effect of Biochar Treated Sewage Sludge on the Yield and Uptake of Copper and Zinc in Chinese Cabbage (Brassica rapa)
}

\author{
Hendrix Chalwe ${ }^{1}$, Mildred Muwowo ${ }^{1} \&$ Lydia Mumbi Chabala ${ }^{1}$ \\ ${ }^{1}$ School of Agricultural Sciences, Department of Soil Science, University of Zambia, Lusaka, Zambia \\ Correspondence: Lydia M. Chabala, School of Agricultiral Sciences, Department of Soil Science, University of \\ Zambia, P.O. Box 32379, Lusaka, Zambia. E-mail: lchabala@unza.zm
}

Received: February 2, 2021

Accepted: March 20, $2021 \quad$ Online Published: May 15, 2021

doi:10.5539/jas.v13n6p48

URL: https://doi.org/10.5539/jas.v13n6p48

The research was financed by the National Science and Technology Council (NSTC) of Zambia as part of a Trilateral Research Project.

\begin{abstract}
One of the potential uses of treated sewage sludge is its application as a soil conditioner in agricultural fields. A factorial experiment was conducted to compare the main effects of biochar and sewage sludge and the interaction effect between biochar and sewage sludge on the plant uptake of copper and zinc and vegetable yield. The experiment was done in a green house and Chinese cabbage was used as the test crop. The experiment consisted of two factors namely, biochar and sewage sludge, each of which was applied to the soil at four levels. The copper and zinc concentration were determined in the laboratory based on Atomic Absorption Spectroscopy. A two-way analysis of variance test was performed, and the Tukey's HSD test was used to separate statistically significant treatment means at $5 \%$ level of significance. Results showed a significant interaction effect between biochar and sewage sludge $(\mathrm{p}=0.012)$ on the level of copper concentration in plant tissue. It was observed that sewage sludge had a significant effect on zinc concentration $(\mathrm{p}<0.001)$ in the plant tissue while biochar did not show any significant effect. Further, results showed significant increase in dry matter yield of Chinese cabbage with increasing levels of biochar applied $(p<0.001)$. This study demonstrates that biochar-treated sewage sludge has potential for use as a soil conditioner in vegetable production. However, it is recommended that care should be taken to avoid overuse by utilizing evaluated and treated sludge for soil amendment.
\end{abstract}

Keywords: biochar-treated sewage sludge, copper, zinc

\section{Introduction}

In some peri-urban areas of Africa, the primary means of sanitation are pit latrines, partly due to the high cost that comes with handling and transportation of faecal sludge. However, the sludge has potential to contaminate soil and ground water sources. For instance, a study by Łuczkiewicz (2006) showed that nitrogen compounds, such as nitrate and ammonium, as well as some heavy metals ( $\mathrm{Ni}$ and $\mathrm{Cd}$ ) originating from the sewage sludge can reach deeper than $0.8 \mathrm{~m}$ and cause the contamination of shallow aquifers. However, in recent years, the use of sewage sludge in agricultural lands has become common both as a way of disposal and for soil enrichment (Mantovi et al., 2005; Grobelak, et al., 2019). Sewage sludge has been reported to improve soil properties, increase crop productivity (Passuello et al., 2012), maintain and restore the quality of previously degraded soils along with reducing the need for synthetic fertilizers (Ojeda et al., 2003). Other materials such as biochar have also been used as soil conditioners in agricultural fields (Gao \& Thomas, 2016).

When combined with soil, biochar can raise soil $\mathrm{pH}$, which is important for the removal of microbiological pathogens such as Escherichia coli (Mohanty et al., 2014). Biochar has also been reported to act as a barrier against organic pollutants and heavy metals preventing them from percolating into groundwater aquifers or polluting nearby surface waters. Biochar- amended soils also have the potential to significantly reduce nitrogen leaching and carbon dioxide emissions (Aghoghovwia, 2018).

In a recent study, Rogers et al. (2018) reported on the development of a hybrid system for recycling black water treated with granular activated carbon to achieve full disinfection and liquid quality more suitable for onsite reuse. One of the benefits of this strategy is that latrine contents saturated with activated carbon (or biochar) can 
then be used as a soil conditioner in agricultural fields. Bai et al. (2018) demonstrated how the cation exchange capacity (CEC) of the soil increased from 8.4 to $13.6 \mathrm{cmol} \mathrm{kg}^{-1}$ when a control soil (with no biochar) was compared to urine saturated with biochar after 140 days. In addition, the biochar increased the soil $\mathrm{pH}$ by 0.9 units, further demonstrating how biochar added to pit latrine sludge can benefit reuse as a soil conditioner. Further, incorporation of biochar at the rate of $40 \mathrm{t} \mathrm{ha}^{-1}$ was reported to effectively reduce the mobility of cadmium and lead from the topsoil layer to the subsurface soil (Feng et al., 2019). The restoration of organic carbon in soils has been found to be possible by adding biochar, with or without fertilizers and compost (Lehmann et al., 2006).

In view of the soil fertility benefits derived from amending soils with sewage sludge, there is a growing trend among some urban communities of Zambia in using sewage sludge as a soil conditioner for lawns and vegetable gardens, with reports of up to $39 \%$ sludge use in vegetable gardens (Kalikenka, 2012). In this study, we evaluated the effect of biochar-treated sewage sludge on yield and selected heavy metal concentration in vegetables. Specifically, we aimed to determine the effect of amending soil with sewage sludge treated with two types of biochar on dry matter yield and concentrations of copper $(\mathrm{Cu})$ and zinc $(\mathrm{Zn})$ in the plant tissue. The test crop used in the experiment was Chinese cabbage (Brassica rapa).

\section{Materials and Methods}

\subsection{Description of Study Site and Soil Characterization}

The study was set up as a pot experiment in a greenhouse at the University of Zambia (UNZA) located at $15^{\circ} 23^{\prime}$ $\mathrm{S}$ and $28^{\circ} 20^{\prime} \mathrm{E}$ in Lusaka, Zambia. The soil was collected from the UNZA field research demonstration station and was classified as Typic Isohyperthemic Paleustalf (Banda \& Chabala, 2006) using the Keys to Soil Taxonomy by Soil Survey Staff (2003) and as Ferric Luvisols according to the World Reference Base (IUSS WORKING GROUP WRB, 2006). The soil was pre-characterized for selected soil properties before the experiment was set up. In this ragrad, the soil reaction $(\mathrm{pH})$ was determined by measuring soil $\mathrm{pH}$ in $0.01 \mathrm{M}$ $\mathrm{CaCl}_{2}$ using a soil to solution ratio of 1:2.5 (Mclean, 1982). The total nitrogen was determined using the Kjeldahl method (Bremner \& Mulvaney, 1982) while available phosphorus was measured following the Bray 1 method (Bray \& Kurtz, 1945). Exchangeable potassium was extracted using $1 \mathrm{~N} \mathrm{NH}_{4} \mathrm{OAc}$ (Thomas, 1982), and its concentration was measured by using the Atomic Absorption Spectrophotometer. The soil organic carbon (SOC) was determined by the Walkley-Black chromate reduction procedure (Allison, 1965; van Reeuwijk, 2002). The zinc and copper in sewage sludge and biochar were determined by complete combustion of the sample and digesting the ash with $1 \mathrm{M}$ nitric acid solution.

\subsection{Green House Experiment}

The experiment was laid out as a factorial design with two factors replicated three times. The first factor was sewage sludge which was at 4 levels of $0,5,10$, and $20 \%$ representing 'none', 'low', 'medium' and 'high' level of application, respectively. The other factor was biochar, which was also at four (4) levels of $0,1.5,3$ and $4.5 \%$ representing 'none', 'low', 'medium' and 'high' level of application, respectively. In both factors, the control treatment was the one where nothing was applied. Plastic pots were then filled with combinations of soil, sewage sludge and biochar at different levels and labelled accordingly. These combinations were made on weight basis as a proportion of the $2 \mathrm{~kg}$ of growth media in each pot. Table 1 below shows a summary of the treatment combinations.

Five (5) seeds of Chinese cabbage (Brassica rapa) were planted in each pot and later thinned to one plant per pot after seedling emergence. The plants were well-watered and received equal amounts of water during the growing period. Other crop management activities included periodic aeration of the growth media and regular weeding to ensure weed-free growing conditions. The crop was grown for six weeks and was harvested by cutting the above ground biomass. The biomass was oven dried at $70{ }^{\circ} \mathrm{C}$ for 48 hours to get the dry weight. The dried Chinese cabbage was then ground into powder for the analysis of the metal content in the plant tissue.

\subsection{Determination of $\mathrm{Cu}$ and $\mathrm{Zn}$ Content in Plant Tissue}

To determine the effects of the various treatment combinations on zinc and copper content in the Chinese cabbage grown in soils amended with biochar-treated sewage sludge, the concentrations of $\mathrm{Cu}$ and $\mathrm{Zn}$ were determined in the dried above-ground plant tissue. One gram of dry and powdered plant tissue was placed in a muffle furnace set at 450 ${ }^{\circ} \mathrm{C}$ for 2 hours. The dry plants were ashed and dissolved in $20 \mathrm{ml}$ of $1 \mathrm{M}$ nitric acid. Copper and Zinc concentrations in the dissolved sample solutions were measured using the Atomic Absorption Spectrometer (Perkin Elmer Analyst 400). 
Table 1. Treatment combinations for the greenhouse experiment

\begin{tabular}{lll}
\hline Biochar (\%) & Sewage sludge (\%) & Treatment combinations (\% Biochar, \%Sewage sludge) \\
\hline 0 (none) & 0 (none) & 0,0 (none, none) \\
1.5 (low) & 0 (none) & $1.5,0$ (low, none) \\
3 (medium) & 0 (none) & 3,0 (medium, none) \\
4.5 (high) & 0 (none) & $4.5,0$ (high, none) \\
0 (none) & 5 (low) & 0,5 (none, low) \\
1.5 (low) & 5 (low) & $1.5,5$ (low, low) \\
3 (medium) & 5 (low) & 3,5 (medium, low) \\
4.5 (high) & 5 (low) & $4.5,5$ (high, low) \\
0 (none) & 10 (medium) & 0,10 (none, medium) \\
1.5 (low) & 10 (medium) & $1.5,10$ (low, medium) \\
3 (medium) & 10 (medium) & 3,10 (medium, medium) \\
4.5 (high) & 10 (mmedium) & $4.5,10$ (high, medium) \\
0 (none) & 20 (high) & 0,10 (none, high) \\
1.5 (low) & 20 (high) & $1.5,20$ (low, high) \\
3 (medium) & 20 (high) & 3,20 (medium, high) \\
4.5 (high) & 20 (high) & $4.5,20$ (high, high) \\
\hline
\end{tabular}

\subsection{Data Analysis}

A two-way Analysis of Variance test was performed on data for both the yield and metal content in Chinese cabbage to determine the effect of biochar and sewage sludge. The Tukey's HSD test was used to separate statistically significant treatment means (Tukey, 1949). Statistical results were judged at $5 \%$ level of significance. Additionally, the metal content in plant tissue was compared with permissible limits for human consumption based on the general standards for contaminants and toxins in food and feed by the joint Commission Codex Alimentarius Commision (FAO/WHO, 2019) as outlined in Table 2 below. All analyses were done in R software (R Core Team, 2020).

Table 2. Permissible limits on selected metals for leafy vegetables

\begin{tabular}{ll}
\cline { 2 - 2 } Heavy metal & Permissible amount $\mathbf{( m g} / \mathbf{k g})$ \\
\cline { 2 - 3 } Copper & 40 \\
Zinc & 60 \\
\hline
\end{tabular}

Source: FAO/WHO (2019).

\section{Results and Discussion}

\subsection{Baseline Characteristics of Soil, Biochar and Sewage Sludge}

Table 3 below shows the properties of the soil, sewage and biochar before the treatments were appliesd. The soil had low levels of copper and zinc at $2.8 \mathrm{mg} / \mathrm{kg}$ and $6 \mathrm{mg} / \mathrm{kg}$, respectively. On the other hand, the sewage sludge had high levels of zinc at $669.33 \mathrm{mg} / \mathrm{kg}$ while the copper concentration was $64.48 \mathrm{mg} / \mathrm{kg}$.

Table 3. Characteristics of soil, biochar and sewage sludge before experimental set up

\begin{tabular}{llllllll}
\hline & $\begin{array}{l}\text { Total Zinc } \\
(\mathrm{mg} / \mathrm{kg})\end{array}$ & $\begin{array}{l}\text { Total Copper } \\
(\mathrm{mg} / \mathrm{kg})\end{array}$ & $\begin{array}{l}\mathrm{P} \\
(\mathrm{mg} / \mathrm{kg})\end{array}$ & $\begin{array}{l}\mathrm{K} \\
(\mathrm{cmol} / \mathrm{kg})\end{array}$ & $\begin{array}{l}\text { Total N } \\
(\mathrm{mg} / \mathrm{kg})\end{array}$ & $\begin{array}{l}\text { Organic Matter } \\
(\%)\end{array}$ & $\mathrm{pH}$ \\
\hline Soil & 6 & 2.8 & 2.77 & 0.04 & 1.66 & 1.20 & 5.86 \\
Sewage-Sludge & 669.33 & 64.48 & 2.33 & 1.81 & 6.11 & & \\
Maize cob Boichar & 27.51 & 3.77 & & & & & \\
Activated Charcoal & 4.59 & 4.41 & & & & & \\
\hline
\end{tabular}

Source: Authors' laboratory results.

\subsection{Effect of Biochar Type, Biochar Level and Sewage Sludge Level on Dry Matter Yield of Chinese Cabbage}

Results showed that the dry matter yield of Chinese cabbage was not significantly affected by biochar type $(\mathrm{p}=$ 0.71, Appendix A). However, dry matter yield was higher at higher levels of biochar ( $p<0.001$, Appendix A). 
Figure 1 shows that dry matter yield was higher at both 3 and $4.5 \%$ biochar levels compared with the control soil. This could be attributed to an improvement in soil quality due to the addition of biochar to the soil. According to Ngulube et al (2018) biochar at the rate of $2 \% \mathrm{w} / \mathrm{w}$ was associated with an increase in soil $\mathrm{pH}$ from 5.5 to 7.15 coupled with $75 \%$ increase in the cation exchange capacity of the soil and subsequently resulting in $28 \%$ increase in dry matter yield in groundnuts. Similarly, Lehmann and Joseph (2009), Cornelissen et al., 2013 and Zhang, et al., 2012 reported significant improvements in soil quality due to biochar.

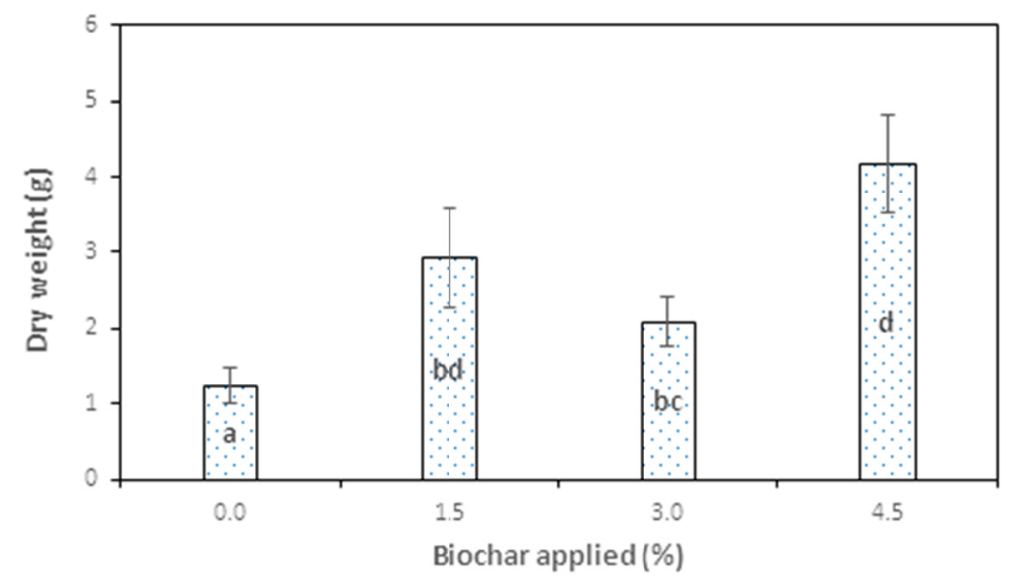

Figure 1. Effects of biochar on dry matter yield of Chinese cabbage (Error bars represent standard error of the mean. Data columns with the same letter(s) are not statistically different)

A similar trend was observed with sewage sludge. The dry matter yield of Chinese cabbage increased significantly with increasing levels of sewage sludge applied to the soil $(\mathrm{p}<0.001)$, indicating a good yield outcome. The yield was higher at all levels of sewage sludge when compared with the control treatment (Figure 2). This result clearly demonstrates that the beneficial effects of amending soils with sewage sludge for the sole purpose of yield improvement cannot be disputed as has been documented in related studies. For instance, Chui et al. (1992) reported significant yield increase in Chinese white cabbage between control and sludge-amended plants. In another study focusing on soil amendment with biochar produced by sewage sludge pyrolysis, it was reported that "applying sewage sludge biochar to infertile and polluted soils promoted plant growth and increased the fresh matter weight of Chinese cabbage" (Liu et al., 2014).

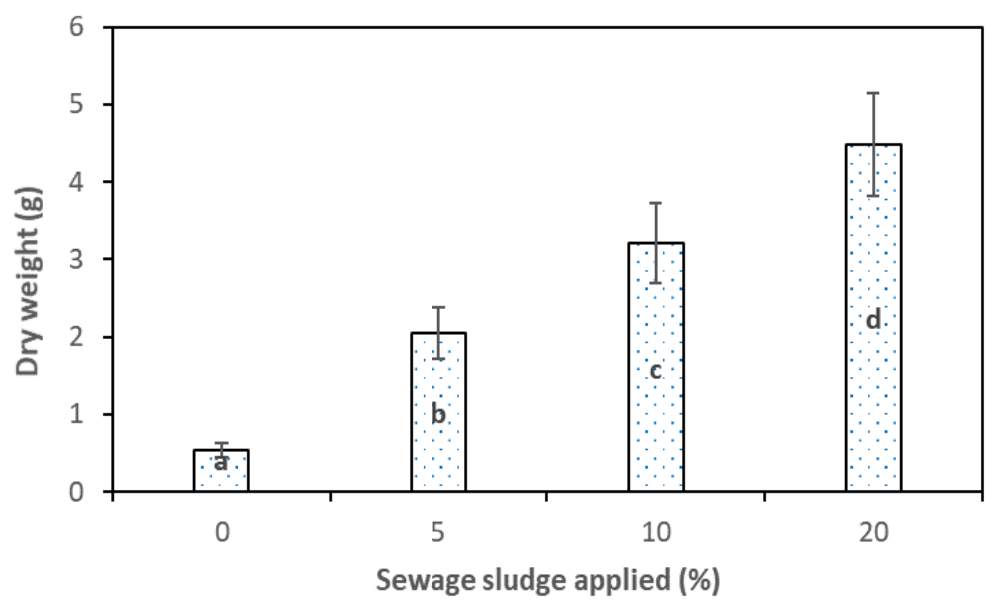

Figure 2. Effect of sewage sludge on drymatter yield of Chinese cabbage. (Error bars represent standard error of the mean. Data columns with the same letter(s) are not statistically different) 
3.3 Effect of Biochar Type, Biochar Level and Sewage Sludge on the Concetration of Zinc and Copper in Chinese Cabbage

Results from the current study showed significant differences in the mean concentration of copper in Chinese cabbage attributable to the various treatment combinations $(p=0.001$, Appendix B). Copper concentration was higher at all sewage sludge levels when compared with the control (Figure 3). This result entails that sewage sludge is an important source of $\mathrm{Cu}$ to the soil. However, it is important to note that the mean copper concentration for each of the different levels of sewage sludge was by far less than the permissible limit of 40 $\mathrm{mg} / \mathrm{kg}$ according to the FAO/WHO (2019) standards as outlined in Table 3 above.

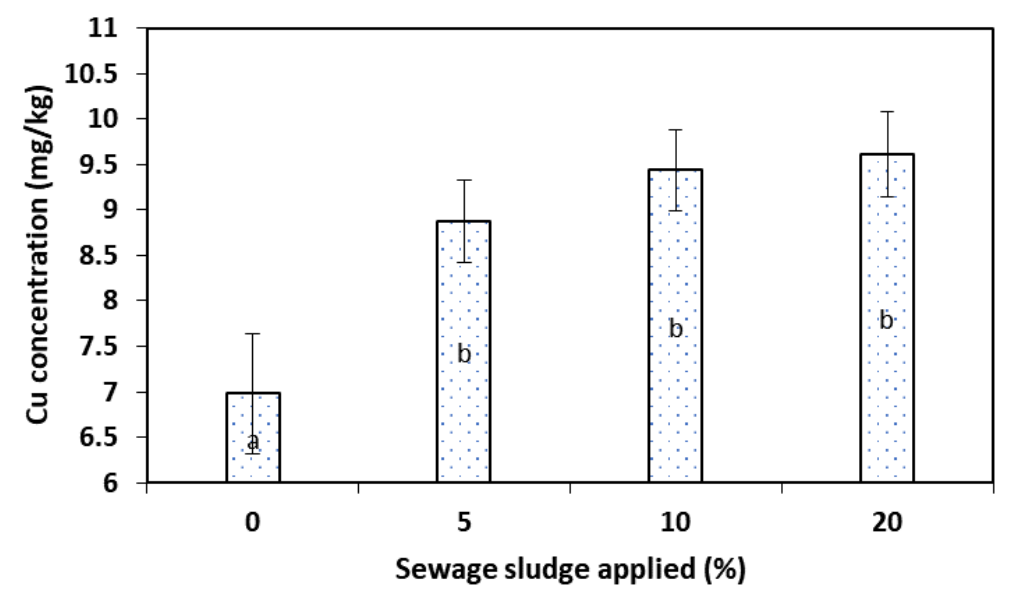

Figure 3. Effect of sewage sludge on copper concentration in Chinese cabbage

Additionally, a significant interaction effect between biochar and sewage sludge $(p=0.014)$ on the level of copper concentration in plant tissue was observed (Figure 4) indicating that the action of biochar and sewage sludge was interdependent. It was shown that the concentration of copper in plant tissue tended to be higher at lower levels of biochar in the non-zero sewage sludge treatments (Figure 4), which entails that biochar when combined with sewage sludge had the capacity to bind some copper in the soil and make it unavailable for plant uptake. Similar results have been reported in related studies (Xincai et al., 2011; Tomczyk et al., 2019; Ramalingham et al., 2020; Burk et al., 2020; Luka et al., 2014).

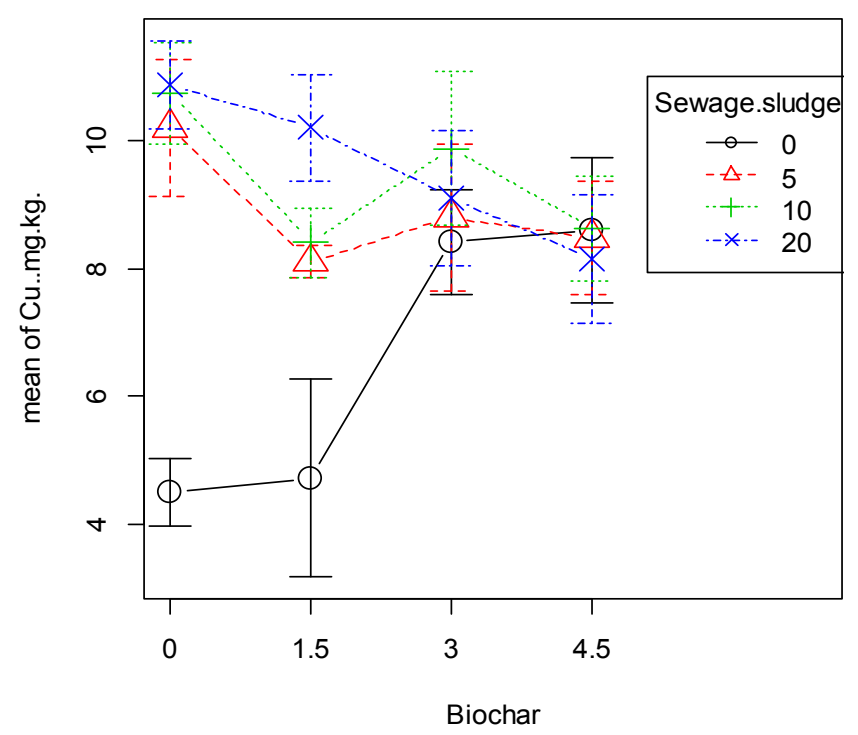

Figure 4. Interaction plot between biochar and sewage sludge 


\subsection{Zinc Concentration in Chinese Cabbage}

A two-way analysis of variance test showed that sewage sludge had a significant effect on zinc concentration ( $p$ $<0.001$, Appendix C) in the plant tissue while biochar did not show any significant effect. Further, no significant interaction between biochar and sewage sludge $(\mathrm{p}=0.57$, Appendix $\mathrm{C})$ on the levels of zinc in plant tissue was observed. The concentration of zinc in the Chinese cabbage increased with increasing rates of sludge application (Figure 4). At every rate of sewage sludge applied, the zinc content in the plant tissue was significantly higher at the higher rates than the lower rates. When compared with the FAO/WHO (2019) permissible limits shown in Table 2 above, only the control had mean zinc concentration within the acceptable level of $60 \mathrm{mg} / \mathrm{kg}$. All the other levels of sewage sludge yielded plants with zinc concentration way above the safe limits. These results reflect the high levels of zinc that was in the sewage sludge prior to its application. This entails that with high levels of zinc in the sewage sludge the incorporation of biochar did not affect its plant uptake.

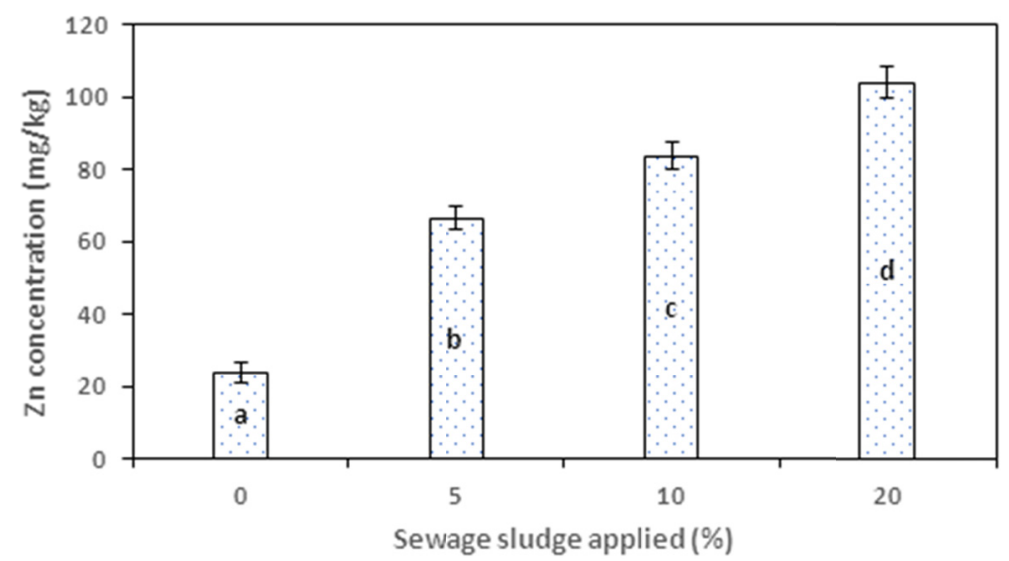

Figure 4. Effect of sewage sludge on zinc concetration in Chinese cabbage

\section{Conclusions}

Biochar treated sewage sludge can potentially be used as a soil conditioner in agricultural fields. In this study, a significant increase in dry matter yield of Chinese cabbage with increasing levels of biochar applied was observed. It was shown that there was a significant interaction between biochar and sewage sludge on the levels of copper concetration in plant tissue indicating that the action of biochar and sewage sludge was interdependent. In the case of zinc, no interaction between biochar and sewage sludge was observed. It was shown that the levels of zinc concetration in Chinese cabbage increased with higher application rates of sewage sludge to levels above the safe limits in vegetables. This indicates that proper evaluation and pre-treatment of sewage sludge is required before it can be used in vegetable production.

\section{Acknowledgements}

This work was financially supported by the National Science and Technology Council (NSTC) of Zambia as part of a Trilateral project. The authors gratefully acknowledge anonymous reviewers for their useful comments and suggestions.

\section{References}

Aghoghovwia, M. P. (2018). Effect of different biochars on inorganic nitrogen availability. Stellenbosch: Stellenbosch University.

Allison, L. E. (1965). Organic carbon. In C. A. Black (Eds.), Methods of Soil Analysis. Part 2. Chemical and Microbiological Properties (pp. 1367-1378). American Society of Agronomy, Madison. https://doi.org/ 10.2134/agronmonogr9.2.c39

Bai, X., Li, Z., Zhang, Y. et al. (2018). Recovery of Ammonium in Urine by Biochar Derived from Faecal Sludge and Its Application as Soil Conditioner. Waste Biomass Valor, 9, 1619-1628. https://doi.org/10.1007/ s12649-017-9906-0

Banda, D. J., \& Chabala, L. M. (2006). Detailed soil survey of the Field Station for the School of Agricultural Sciences. Report for the Department of Soil Science, University of Zambia. 
Bray, R. H., \& Kurtz, L. T. (1945). Determination of total, organic and available forms of phosphorus in soils. Soil Science, 59, 39-45. https://doi.org/10.1097/00010694-194501000-00006

Bremner, J. M., \& Mulvaney, C. S. (1982). Nitrogen-Total. In A. L. Page, R. H. Miller \& D. R. Keeney (Eds.), Methods of Soil Analysis, Part 2: Chemical and Microbiological Properties (2nd ed.). ASA, SSA, Madison, Wisconsin, USA.

Burk, G. A., Herath, A., Crisler, G. B., Bridges, D., Patel, S., Pittman Charles, U., \& Todd, M. (2020). Cadmium and Copper Removal from Aqueous Solutions Using Chitosan-Coated Gasifier Biochar. Frontiers in Environmental Science, 8, 186. https://doi.org/10.3389/fenvs.2020.541203

Chui, V. W. D., Lam-Leung, M. S. Y., Cheung, M., \& Wu, V. K. C. (1992). The use of sewage sludge as basal dressing for vegetable cultivation. Environmental International, 18(2), 201-209. https://doi.org/10.1016/ 0160-4120(92)90007-Q

Cornelissen, G., Martinsen, V., Shitumbanuma, V., Alling, V., Breedveld, G. D., Rutherford, D. W., ... Mulder, J. (2013). Biochar Effect on Maize Yield and Soil Characteristics in Five Conservation Farming Sites in Zambia. Agronomy, 3, 256-274. https://doi.org/10.15406/apar.2016.04.00150

Feng, J., Xiaomin, C., Xin, W., Wei, L., Shimin, H., Zhijiang, Y., ... Yanling, X. (2019). Biochar effects on soil chemical properties and mobilization of cadmium $(\mathrm{Cd})$ and lead $(\mathrm{Pb})$ in paddy soil. Soil Use and Management, 36(2), 320-327. https://doi.org/10.1111/sum.12557

Food and Agriculture Organization/World Health Organization. (2019). General standards for contaminants and toxins in food and feed by the Joint FAO/WHO Codex Alimentarias Commission.

Gao, S., \& Thomas, H. D. L. (2016). Influence of biochar on soil nutrient transformations, nutrient leaching, and crop yield. Adv Plants Agric Res, 4(5), 348-362. https://doi.org/10.15406/apar.2016.04.00150

Grobelak, A., \& Jaskulak, M. (2019). Sludge multifunctions in a phytobiome-Forest and plantation application including microbial aspects. Industrial and Municipal Sludge (pp. 323-336). https://doi.org/10.1016/ b978-0-12-815907-1.00014-3

IUSS WORKING GROUP WRB. (2006). World Reference Base for Soil Resources 2006 (World Soil Resources Reports No. 103). FAO, Rome.

Kalikenka, M. (2012). Sustainable use of sewage sludge as a soil conditioner-The Zambian case study. Conference: Use of sewage sludge as a soil conditioner, Kitwe, Zambia. Retrieved from https://www.researchgate.net/publication/342888160_SUSTAINABLE_USE_OF_SEWAGE_SLUDGE_AS _A_SOIL_CONDITIONER-THE_ZAMBIAN_CASE_STUDY

Lehmann, J., \& Joseph, S. (2009). Biochar for Environmental Management: Science and Technology. Earthscan, London.

Lehmann, J., Gaunt, J., \& Rondon, M. (2006). Bio-char Sequestration in Terrestrial Ecosystems-A Review. Mitigation and Adaptation Strategies for Global Change, 11(2), 403-427. https://doi.org/10.1007/ s11027-005-9006-5

Liu, T., Liu, B., \& Zhang, W. (2014). Nutrients and Heavy Metals in Biochar Produced by Sewage Sludge Pyrolysis: Its Application in Soil Amendment. Polish Journal of Environmental Studies, 23(1), 271-275.

Łuczkiewicz, A. (2006). Soil and Groundwater Contamination as a Result of Sewage Sludge Land Application. Polish J. of Environ. Stud., 15(6), 869-876.

Luka, S. T., Roman, S., Hana, S., Dagmara, F. K., \& Michael, K. (2014). Copper removal from aqueous solution using biochar: Effect of chemical activation. Arabian Journal of Chemistry, 7, 43-52. https://doi.org/10.1016/ j.arabjc.2013.08.001

Mantovi, P., Baldoni, G., \& Toderi, G. (2005). Reuse of liquid, dewatered, and composted sewage sludge on agricultural land: effects of long-term application on soil and crop. Water Research, 39(2-3), 289-296. https://doi.org/10.1016/j.watres.2004.10.003

Mclean, E. O. (1982). Soil pH and Lime Requirement. In A. L. Page, R. H. Miller \& D. R. Keeney (Eds.), Methods of Soil Analysis, Part 2: Chemical and Microbiological Properties (2nd ed.). ASA, SSA, Madison, Wisconsin. 
Mohanty, S. K., Cantrell, K. B., Nelson, K. L., \& Boehm, A. B. (2014). Efficacy of biochar to remove Escherichia coli from storm water under steady and intermittent flow. Water Research, 61, 288-296. https://doi.org/ 10.1016/j.watres.2014.05.026

Ngulube, M., Mweetwa, A. M., Phiri, E., Njoroge, S. M. C., Chalwe, H., Shitumbanuma, V., \& Brandenburg, R. L. (2018). Effects of biochar and gypsum soil amendments on groundnut (Arachis hypogaea L.) dry matter yield and selected soil properties under water stress. African Journal of Agricultural Research, 13(21), 1080-1090. https://doi.org/10.5897/AJAR2018.13123

Ojeda, G., Alcaniz, J. M., \& Ortiz, O. (2003). Runoff and losses by erosion in soils amended with sewage sludge. Land Degrad. Dev., 14(6), 563-573. https://doi.org/10.1002/ldr.580

Passuello, A., Cadiach, O., Perez, Y., \& Schuhmacher, M. (2012). A spatial multicriteria decision making tool to define the best agricultural areas for sewage sludge amendment. Environ. Int., 38, 1-9. https://doi.org/ 10.1016/j.envint.2011.07.013

R Core Team. (2020). R: A language and environment for statistical computing. R Foundation for Statistical Computing, Vienna, Austria. Retrieved from https://www.R-project.org

Ramalingham, S., \& Donipathi, M. R. P. (2020). Sorption of Heavy Metal onto Biochar. Applications of Biochar for Environmental Safety. https://doi.org/10.5772/intechopen.92346

Rogers, T. W., Rogers, T. S., Stoner, M. H., Sellgren, K. L., Lynch, M. J., Forbis-Stokes, A. A., ... Hawkins, B. T. (2018). A granular activated carbon/electrochemical hybrid system for onsite treatment and reuse of blackwater. Water Research, 144, 553-560. https://doi.org/10.1016/j.watres.2018.07.070

Soil Survey Staff. (2003). Keys to Soil Taxonomy (9th ed.). Washington, DC: US Department of Agriculture, Natural Resources Conservation Service.

Thomas, G. W. (1982). Exchangeable Cations. In A. L. Page, R. H. Miller \& D. R. Keeney (Eds.), Methods of Soil Analysis, Part 2: Chemical and Microbiological Properties (2nd ed.). ASA, SSA, Madison, Wisconsin, USA.

Tomczyk, A., Boguta, P., \& Sokołowska, Z. (2019). Biochar efficiency in copper removal from Haplic soils. Int. J. Environ. Sci. Technol., 16, 4899-4912. https://doi.org/10.1007/s13762-019-02227-4

Tukey, J. W. (1949). Comparing individual means in the Analysis of Variance. Biometrics, 5(2), 99-114. https://doi.org/10.2307/3001913

van Reeuwijk, L. P. (2002). Procedures for Soil Analysis. International Soil Reference and Information Centre Technical Paper No. 9 (6th ed.). Anneka Mordhorst, the Netherlands.

Xincai, C., Guangcun, C., Linggui, C., Yingxu, C., Johannes, L., Murray, B. M., \& Anthony, G. H. (2011). Adsorption of copper and zinc by biochars produced from pyrolysis of hardwood and corn straw in aqueous solution. Bioresource Technology, 102(19), 8877-8884. https://doi.org/10.1016/j.biortech.2011.06.078

Zhang, A., Bian, R., Pan, G., Cui, L., Hussain, Q., Li, L., .. Yu, X. (2012). Effects of biochar amendment on soil quality, crop yield and greenhouse gas emission in a Chinese rice paddy: A field study of 2 consecutive rice growing cycles. Field Crops Research, 127, 153-160. https://doi.org/10.1016/j.fcr.2011.11.020 


\section{Appendix A}

Analysis of Variance (ANOVA) output table on the effect of biochar treated sewage sludge on dry-matter yield

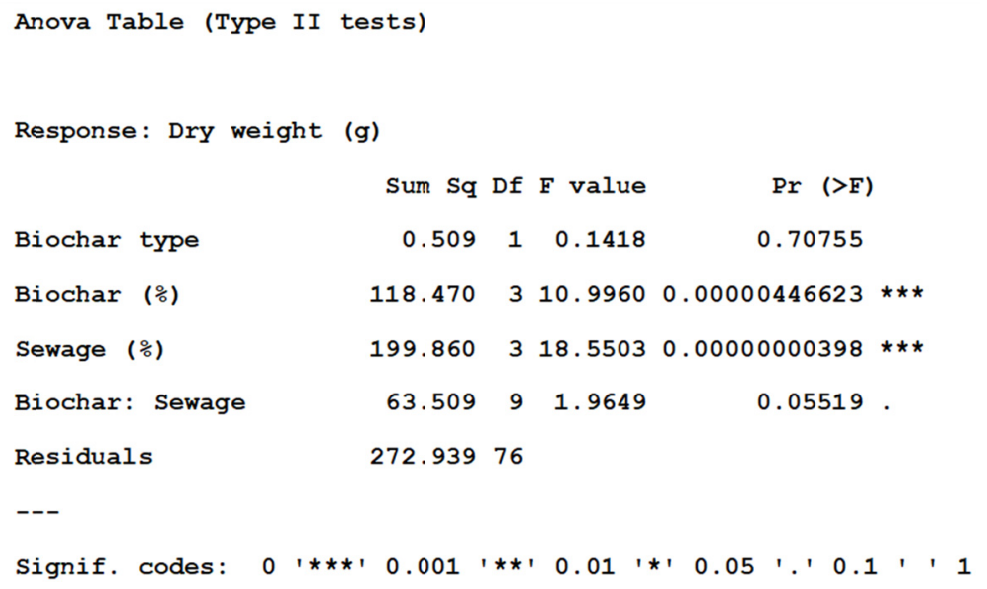

\section{Appendix B}

Analysis of Variance (ANOVA) output table on the effect of biochar treated sewage sludge on copper concentration in the plant tissue

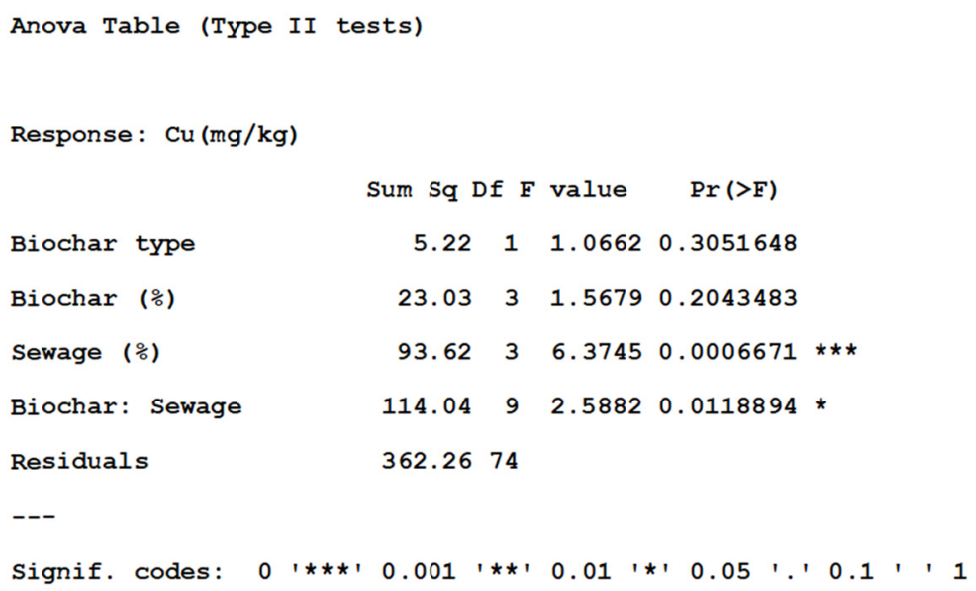

\section{Appendix C}

Analysis of Variance (ANOVA) output table on the effect of biochar treated sewage sludge on zinc concentration in the plant tissue

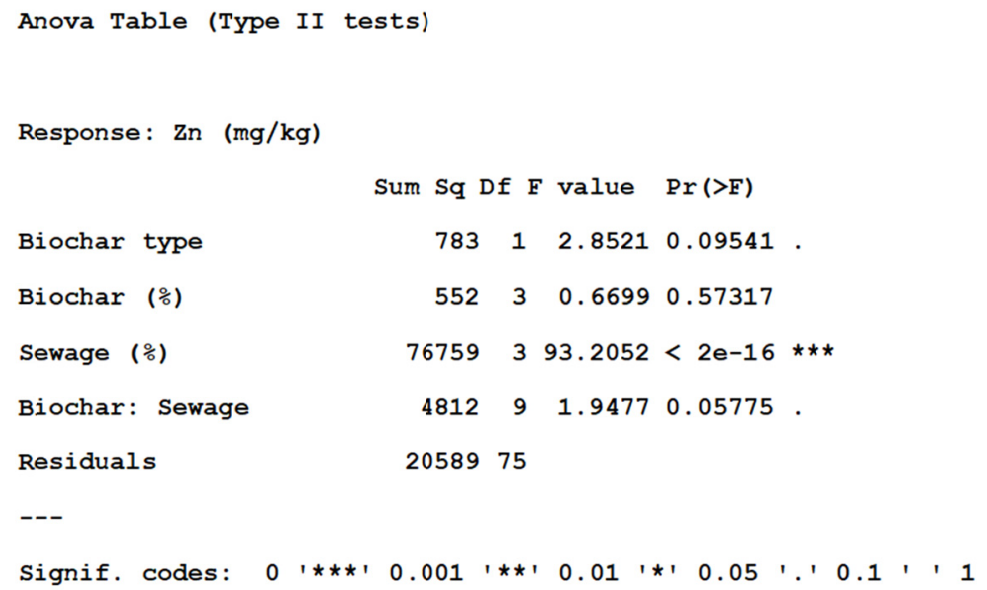




\section{Copyrights}

Copyright for this article is retained by the author(s), with first publication rights granted to the journal.

This is an open-access article distributed under the terms and conditions of the Creative Commons Attribution license (http://creativecommons.org/licenses/by/4.0/). 